(3) 核医学検査におけるディジタル画像処理の現状と問題点

An overview of digital image processing in the field of Nuclear Medicine

\author{
川崎市立川崎病院核医学検査室＼cjkstart奥山康男
}

【はじめに】近年,核医学画像はココピ ${ }^{\circ}$ タ-の普及とその利用技術の向上により,動態画像及びSPECT画

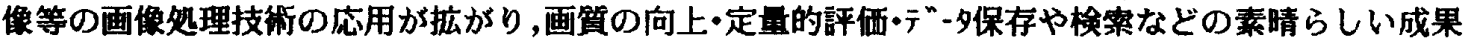
がみられる。そうした中で核医学デ付”外画像处理の現状と問題点について報告する。

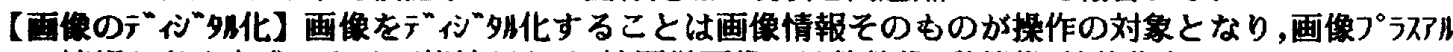

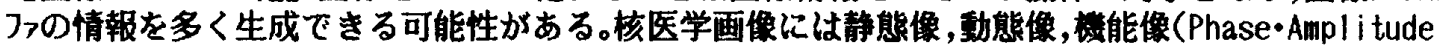
i mage), 再模成断屏像(SPECT・PET image)の種類があり,静態像においては画像の使用状況として5年

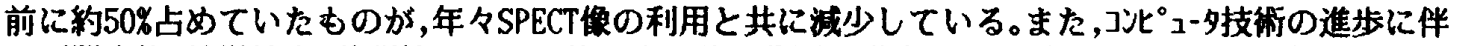

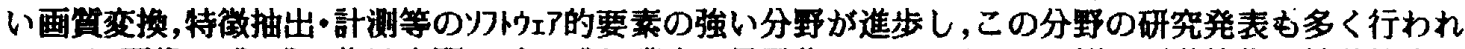

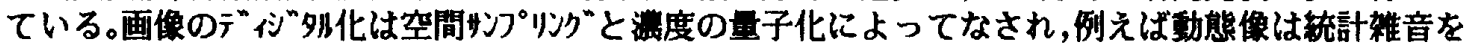
小さくするため大きな画素に分割し，静態像虫解像力を重視するため細かく分割する。現在のシ沉ムで

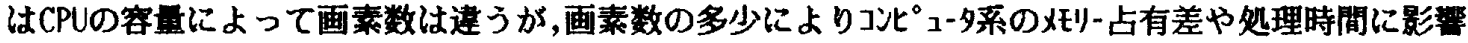
を及ぼすので,CPUの高速溃算处理技術の開発が進められている。また,娭出器系の解保力はFWHM3.5mm ぐらいで,情報理論上は静態像において $256 \times 256$ 訬クスにデジ多化すれば避色ないと思われる。検出 器性能に関してはNaI+フ+ト情を使用するかきり，限界に来ているかと思う。

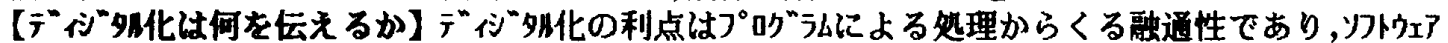
による実行は必然的なむのである。しかし，固人が見やすい画像を容易に作りだせたり,画像抽出・計 测など個々の主钼が大きく入り込む要因む持っていて,従来より確立されていた画像診断論理を崩す

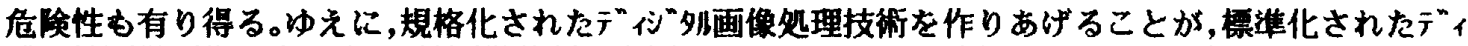

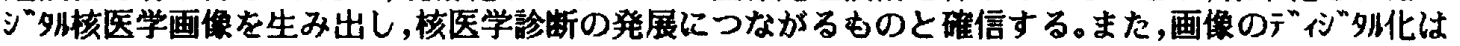

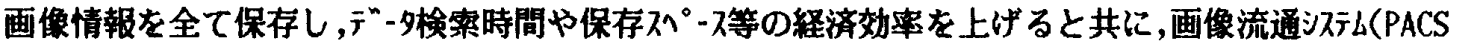
やISAC)などの閉発にも貢献している。

【まとめ】現在の核医学娭查におけるデ付”夘画像処理の問題点と画像解析技術を行う上での考光方

及び,将来的展望を取り混ぜ明らかにした。

\title{
(4) 画像工学者から見た医用画像と光の利用
}

Discussion about medical images from engineering point of view

\section{東京工業大学工学部像情報工学研究施設大山永昭}

近年における計算譏技術のめさましい進歩は、大容量画像の高速処理を可能とし、従来技術では不 可能であった様々な新しい画像機器を実用化している。医滰においても、近年開発されたX線 C Tや M R I 等のディジタルイメージング装专は、新しい画像診断の分野を作り、現在の医療に不可久な診 断機器になっている。これらの機器では、センサーからの生データを画像化するためにディジタル処 理を行っており、このことからも画像処理技術の必要性は明白であるが、今後はさらに物体に関する 先見情報等の知識を導入した処理技術が重要になると予想される。ここで述べる知識処理は、ファジ 一的な睃粕な情報等を取り报える手法であり、従来のA I 手法とは大きく異なっている。この様な知 識処理を実現するためには、X線 C T 画像の再生に代表される処理手法に、知識を定式化した項を付 加した評価関数を設定し、その評価関数が最小になるように画像を回復あるいは再生することが考え られる。この様な評洒関数を用いる方法は、きわめて沉用的であり棣々な問題に適応可能であるが、

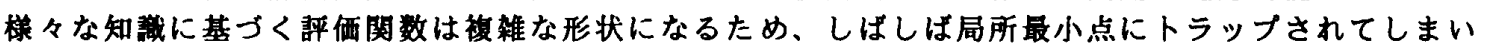
結果として良好な処理結果を得ることが出来なくなってしまう。

焚統計力学を基硅としたシミュレーテッド・アニーリング法は、結晶成长の過程を模したモンテカ ルロ法の一種であり、上記の局斥最小点のトラッブを避け得る手法として近年注目されている。本講 演では、今後の知識処理に関する研究を遂行する上で非常に有効な手法となるシミュレーテッド・ア ニーリング法を解説し、その応用例として血管系の三次元再生に関する各種の計算機シミュレーショ ン結果を紹介する゙'。さらに、画像工学者から見た医用画像の現状における問題点を整理し、その一 つとして、知識の定式化に関する研究の欠如を拍摘する。そして最後に、従来経験により蓄積された 知識の構筑を、計算機システムに導入する可能性を予測し、そのために重要となる踺康医察データフ アイリングシステム゙2の将来形势を展望する。

考支嗝 1) H.Haneishi et al. Optics Letters vol.14, No. 20 (1989) 1095-1097

2) 大山永昭 光学 No. 11 , vol.20（1991）724-730 